\title{
Response of the residential piscivorous fish community to introduction of a new predator type in a mesotrophic lake
}

\author{
Torsten Schulze, Ulrich Baade, Hendrik Dörner, Reiner Eckmann, \\ Susanne S. Haertel-Borer, Franz Hölker, and Thomas Mehner
}

\begin{abstract}
Although the effects of introduced predators on prey populations in aquatic ecosystems have been studied frequently, less is known about the interactions between predators. We performed a whole-lake experiment by stocking a non-native top predator (pikeperch (Sander lucioperca)) to two residential piscivores (Eurasian perch (Perca fluviatilis) and northern pike (Esox lucius)). By analyzing spatial distribution, diet composition, growth, and consumption rates of the piscivores before and after pikeperch introduction, we tested how both density-dependent and trait-mediated responses affected interactions between the three predators. Total piscivore biomass increased 1.5 times and annual consumption by the piscivores increased 1.7 times after stocking, attributable to the stocked pikeperch and increased northern pike abundances. Abundance, distribution, and consumption data indicated that northern pike was hardly affected by pikeperch stocking and even increased its biomass, whereas piscivorous perch shifted its habitat use towards the littoral lake areas in response to competition with pikeperch. Furthermore, all piscivores increasingly fed on small perch. The forced habitat shift of piscivorous perch in combination with increased predation on small perch led to a decreased abundance of large perch, attributable to the compensatory effects of intraguild predation and cannibalism.

Résumé : Alors que les effets des prédateurs introduits sur les populations de proies dans les écosystèmes aquatiques ont souvent été étudiés, les interactions entre les prédateurs eux-mêmes sont moins bien connues. Dans une expérience à l'échelle d'un lac, nous avons ajouté un prédateur supérieur non indigène (" pikeperch » (Sander lucioperca)) à un peuplement de poissons ichtyophages résidents (la perche (Perca fluviatilis) et le grand brochet (Esox lucius)). L'analyse de la répartition spatiale, de la composition du régime alimentaire, de la croissance et des taux de consommation avant et après l'introduction du pikeperch nous a permis de vérifier comment les réactions liées à la densité et celles reliées aux caractéristiques biologiques affectent les interactions entre les trois prédateurs. Après

l'empoissonnement, la biomasse totale des poissons piscivores a augmenté de 1,5 fois et la consommation annuelle des piscivores de 1,7 fois; cela s'explique par l'introduction des pikeperch et l'abondance accrue des grands brochets. Les données sur l'abondance, la répartition et la consommation indiquent que le grand brochet est à peine affecté par l'introduction du pikeperch et qu'il augmente même sa biomasse, alors que la perche piscivore modifie son utilisation de l'habitat et choisit de préférence les zones littorales du lac en réaction à la compétition par le pikeperch. De plus, tous les piscivores se nourrissent davantage de petites perches. Le changement forcé d'habitat des perches piscivores combiné à la prédation accrue sur les petites perches a pour effet de diminuer l'abondance des perches de grande taille, ce qui est attribuable aux effets compensatoires de la prédation et du cannibalisme au sein de la guilde.
\end{abstract}

[Traduit par la Rédaction]

Received 2 June 2005. Accepted 22 April 2006. Published on the NRC Research Press Web site at http://cjfas.nrc.ca on 21 September 2006.

J18721

T. Schulze, ${ }^{1,2}$ H. Dörner, ${ }^{3}$ F. Hölker, and T. Mehner. Department of Biology and Ecology of Fishes, Leibniz-Institute of Freshwater Ecology and Inland Fisheries, P.O. Box 850 119, 12561 Berlin, Germany.

U. Baade. ${ }^{4}$ Department of Biology and Ecology of Fishes, Leibniz-Institute of Freshwater Ecology and Inland Fisheries, P.O. Box 850 119, 12561 Berlin, Germany, and Department of Biology, Limnological Institute, University of Constance, 78457 Constance, Germany.

R. Eckmann and S.S. Haertel-Borer. ${ }^{5}$ Department of Biology, Limnological Institute, University of Constance, 78457 Constance, Germany.

${ }^{1}$ Corresponding author (e-mail: torsten.schulze@igb-berlin.de).

${ }^{2}$ Present address: University of Natural Resources and Applied Life Sciences, Department of Water, Atmosphere and Environment, Institute of Hydrobiology and Aquatic Ecosystem Management, Max-Emanuel-Straße 17, A-1180 Vienna, Austria.

${ }^{3}$ Present address: European Commission, Joint Research Centre, IPSC Institute for the Protection and Security of the Citizen, AGRIFISH Unit, TP 266, 21020 Ispra, Italy.

${ }^{4}$ Deceased.

${ }^{5}$ Present address: Swiss Fisheries Advisory Service (FIBER), c/o EAWAG, Seestr. 79, 6047 Kastanienbaum, Switzerland. 


\section{Introduction}

Species invasions and introductions may be considered as one of the major threats to global biodiversity and ecosystem stability (Simberloff 1981; Coblentz 1990). Nevertheless, deliberate or intended introductions are widespread in freshwater ecosystems in which stocking of certain fish species is still recommended and a common practice (Lehtonen et al. 1984; Mehner et al. 2004). Within the fisheries perspective, the aims of introducing fish cover several aspects such as filling a "vacant niche", replacing native species with more productive alien species, or controlling water quality (Welcomme 2001). The effects provoked in the stocked ecosystem can be those that were desired, as in the case of biomanipulation (Lathrop et al. 2002), but also devastating effects of introduced piscivorous fish have occurred (Craig 1992).

Whether predator introductions have the desired ecosystem effects depends, among others, on the degree of knowledge available on species interactions. Although direct and indirect effects of predators on their prey populations were often considered (Carpenter and Kitchell 1993; Hansson et al. 1998; Hölker and Mehner 2005), the possible interactions between stocked and residential piscivorous fish species have often been neglected. Coexistence of species faced by competitive interactions is often facilitated by resource segregation along the diet, time, or habitat niche axes (Schoener 1974). Accordingly, niche shifts of the resident competitors in response to introduced competitors might occur. Secondly, because many predators have to grow to large sizes to become piscivorous, size-structured predator-prey interactions between several developmental stages of the piscivores are likely affected (Werner and Gilliam 1984). Intraguild predation and cannibalism are frequent interactions, among others, that may dampen the expected direct density effects on the prey populations (Polis et al. 1989; Arim and Marquet 2004; Claessen et al. 2004). Furthermore, the response of the predators may be additionally influenced by both densitydependent and trait-mediated responses in the prey fish communities (Brabrand and Faafeng 1993; Christensen and Persson 1993; Jacobsen and Perrow 1998).

To elucidate the variety of resulting interactions, we studied the response of two residential predatory species, large Eurasian perch (Perca fluviatilis; $>20 \mathrm{~cm}$ total length $\left(L_{T}\right)$; referred to hereafter as perch) and northern pike (Esox lucius), to the experimental introduction of a new predator, pikeperch (Sander lucioperca), in a small lake in northern Germany. Northern pike and perch are distributed in Europe, Asia, and North America (northern pike only) and are the top piscivores in many lakes of the northern German lowlands (Maitland and Campbell 1992; Mehner et al. 2005a). Northern pike rely on the ambush technique (sit-and-wait predator type), feeding solitarily mainly in the littoral zone, being mostly active during day and twilight (Eklöv 1992; Maitland and Campbell 1992; Craig 1996). In contrast, perch is a less specialized, predominantly day-active fish undergoing several ontogenetic niche shifts and foraging mainly in the pelagic zones (Popova and Sytina 1977; Craig 1987). Into this set of residential predators, we introduced pikeperch, a species that naturally did not occur in northern Germany but has been introduced into many waters to enhance fisheries yield and to suppress unwanted cyprinid species in biomanipulation approaches (Mehner et al. 2004). Pikeperch is a solitary ambush-pursuit predator patrolling the pelagic zones of lakes (Popova and Sytina 1977; Maitland and Campbell 1992). In contrast to perch and northern pike, pikeperch is found highly active during twilight and also at night (Popova and Sytina 1977; Fedorova and Drozzhina 1982).

Empirical data on sympatric populations of northern pike, large perch, and pikeperch are scarce (Svärdson and Molin 1973). According to the single-species studies available, we expected that pikeperch would more strongly interfere with perch than with northern pike because of the stronger habitat overlap among the two percids. Furthermore, we expected that the introduction of pikeperch would lead to both competitive and predator-prey interactions within the piscivorous feeding guild. We considered four not mutually exclusive effects of the ecosystem perturbation. (i) The residential northern pike and perch share their prey resources with pikeperch such that growth and consumption rates will decline in the two residential species, but probably at different magnitudes. (ii) At least one of the two residential predator species responds to introduction by a habitat shift in comparison with usual habitat preference at allopatry (Werner and Hall 1977). (iii) At least one of the two residential predators responds with a shift to other fish prey (Hanson and Leggett 1986) or even includes new prey resources, for example, from benthic origin (Persson 1986). (iv) Because of diet switches and altered prey selectivity, predator-prey relationships become the dominant interaction type between the piscivores, and thus intraguild predation and cannibalism will lead to a biomass decline in at least one of the predators. This diet switch might then, in the long term, lead to a return of the overall piscivorous fish abundance to its initial state (Murdoch 1969).

By analyzing spatial distribution, diet composition, growth, and consumption rates of the residential piscivores before and after pikeperch introduction, we tested which of the alternatives contributed strongest to the expected response within the piscivorous fish guild. Furthermore, by studying abundances and distribution of the prey fish populations, we aimed to elucidate whether the response in the residential piscivores was additionally influenced by changes in prey density or behavior.

\section{Material and methods}

\section{Study site}

Lake Großer Vätersee (12 ha, maximum depth $11.5 \mathrm{~m}$, mean depth $5.2 \mathrm{~m}$ ) is situated about $70 \mathrm{~km}$ northeast of Berlin, Germany (60 $\mathrm{m}$ above sea level). The mesotrophic lake has no inflow or outflow, the water level depends on groundwater and the catchment is mostly covered by forest (see Kasprzak et al. (2000) for further details). Most of the lakeshore and the adjacent littoral zones are covered by reed (Phragmites australis) and Chara sp. There is no commercial fishery at the lake, and angling was forbidden for the duration of the experiment. According to the lake owner, pikeperch has not occurred in the lake during the past 100 years such that the residential piscivores were naive to its experimental introduction. Biological features of the lake ecosystem were studied during a 2-year period both before 
(1997 and 1998) and after (2001 and 2002) pikeperch stocking; $782(183.8 \mathrm{~kg})$ and $301(101.4 \mathrm{~kg})$ age-2 pikeperch were stocked in spring 2001 and spring 2002, respectively. Pikeperch were measured (mean $L_{T} \pm$ standard deviation (SD): $2001,30.6 \pm 3.5 \mathrm{~cm} ; 2002,34.3 \pm 4.1 \mathrm{~cm})$ and weighed (see below), and all pikeperch were tagged with passive integrated transponders (PIT tags, TROVAN; except for 152 pikeperch marked by fin clips in 2001) before stocking.

Data of the period without pikeperch were taken, in part, from a study by Haertel et al. (2002). During the period after pikeperch stocking, data collection and processing were performed using the same methods as in Haertel et al. (2002) whenever possible. The methods used in either period are described below.

\section{Fishing, food analyses, and abundance estimates}

To minimize the impact of fishing on piscivorous fish (i.e., large perch, northern pike, and pikeperch), only nonlethal sampling methods were used, and fish were released into the lake after processing. Fishing was done once or twice per month from April to November in 1997 and 2001 and from March to November in 1998 and 2002. In all years, electric fishing was done with low current ( 200V; electrofishing gear with accumulator; Bretschneider Spezialelektronik, Germany) during night and day from a boat with an electrical engine. During night, single fish resting in shallow littoral areas were detected with a spotlight and anaesthetized by a short, low-current pulse. In 2001 and 2002, a set of gill nets with mesh sizes of $25,32,40$, and $50 \mathrm{~mm}$ was also used. Nets were set at day (sunrise to sunset), twilight (sunset to total darkness and total darkness to sunrise), and night (total darkness) and at different depths (littoral zone, $3 \mathrm{~m}$; pelagic zone, $6 \mathrm{~m}, 8 \mathrm{~m}$ (2002 only); surface) for short time intervals (45 to $120 \mathrm{~min}$, depending on water temperature) to minimize mortality. To describe diel activity patterns, standardized fish numbers (catch per unit effort (CPUE) calculated per $100 \mathrm{~m}^{2}$ net panel and exposure time, individuals $\left.\cdot\left(\mathrm{h} \cdot 100 \mathrm{~m}^{2}\right)^{-1}\right)$ were calculated from all nets except the set at the depth of $8 \mathrm{~m}$ because of anoxic conditions during summer. The proportion of habitat use by both prey species was calculated from the simultaneously obtained littoral and pelagic CPUE, separately for day and night periods. From these values, an annual average use (percent of total CPUE) of the littoral (or pelagic) zone was calculated only for those sampling intervals in which $\geq 2$ perch or pikeperch were caught. In contrast, catches with only one fish (i.e., $100 \%$ in either littoral or pelagic areas) were considered to be not representative of the distributions and thus were omitted. To increase the number of fish available for abundance estimates (see below), a fyke net (length of leader, $65 \mathrm{~m}$; mesh size, $16 \mathrm{~mm}$; height, $4.5 \mathrm{~m}$; mesh size of hoop, $12 \mathrm{~mm}$ ) set perpendicular to the shore was used in addition to the other nets during all sampling months in 2002. A beach seine (length of each wing, $300 \mathrm{~m}$; mesh size, 26$18 \mathrm{~mm}$; height, $20 \mathrm{~m}$ ) hauled by a mooring winch was used to remove most of the pikeperch from the lake at the end of the experimental period in November 2002.

All fish were measured and weighed to the nearest $0.5 \mathrm{~cm}$ $L_{T}$ and gram wet mass, respectively. Fishes caught by gill nets, electrofishing, and the beach seine were used for diet analyses. Stomach contents, obtained from anaesthetized fish (tricaine methanesulfonate, MS 222) by flushing them with a compression sprayer, were preserved in $70 \%$ alcohol (1997-1998) or deep frozen $\left(-18{ }^{\circ} \mathrm{C}\right.$; 2001-2002) until further processing in the laboratory. Stomach contents were examined under a stereoscopic microscope. Prey fish were determined to species level and, in case of advanced digestion, identified from remaining hard structures. Prey fish were counted, length was measured, and mass was then backcalculated from length-mass relationships or hard part length-mass relationships obtained from Lake Großer Vätersee fish and crayfish samples. Vertebra length in fish and carapax or claw lengths in crayfish were used to calculate total length and biomass. Index of food selectivity of predators was calculated for the main prey species small roach (Rutilus rutilus, 6-16 cm) and small perch $(6-15 \mathrm{~cm})$ according to Strauss (1979), based on the biomass proportions of these size classes in the calculated yearly consumption rates (see below) and on the lake-wide prey biomass.

On each sampling occasion, all piscivores were checked for tags, and untagged ones were individually tagged with PIT tags injected into the back muscle and released. Population densities were estimated from the mark-recapture data according to Schumacher and Eschmeyer (in Ricker 1975). Population biomass was then derived from the age group (perch) or length class (northern pike) proportions in the samplings and the respective length-mass relationships. For pikeperch, abundance and biomass data were calculated for two groups according to the stocking occasions.

Abundances of prey fish species (small roach and perch) were estimated by multiple mark-recapture experiments in 1998 (Haertel et al. 2002) and 2002. To minimize handling mortality at higher water temperatures, these estimates were restricted to early spring (Haertel et al. 2002). Moreover, a short time frame better approximates the assumption of a closed population in mark-recapture models. Fishes were caught by electrofishing (see above), anaesthetized (MS 222), and measured ( $L_{T}$, to the nearest $\left.1 \mathrm{~mm}\right)$. All fish were tagged with coded wire tags (NMT, Salisbury, USA), which were injected into the dorsal musculature in 1998 (Haertel et al. 2002) or into the head (snout tissue or cheek muscle) in 2002. Tag presence was checked by a portable sampling detector. At each electrofishing operation, all fish were checked for tags, unmarked fish were tagged, and all fish were subsequently released. Population size was calculated according to model $M_{t}$ (Otis et al. 1978; White et al. 1982). Population biomass was derived from length-weight relationships obtained from Lake Großer Vätersee fish samples.

Habitat use of prey fish was investigated in the littoral $(\leq 3 \mathrm{~m}$ water depth) and the pelagic zones. Both habitats were sampled simultaneously during day and night. Sampling took place monthly from May to September 1997 and from May to October 1998 (Haertel et al. 2002). In 2001 and 2002, sampling took place from May to October. All fishing was done by gillnets of $8-15 \mathrm{~mm}$ bar mesh size. In the littoral zone, the nets were set perpendicular to the shoreline at the bottom. In the pelagic zone, floating nets $6 \mathrm{~m}$ high were used, fishing almost the entire zone where fish can survive as the lake is thermally stratified from late April to late October, with an anoxic zone beginning at about $7 \mathrm{~m}$ deep (Kasprzak et al. 2000). The nets were set for $2 \mathrm{~h}$ during day (1000- 
Fig. 1. Abundance (open bars) and biomass (shaded bars) \pm upper and lower $95 \%$ confidence limits of northern pike (Esox lucius), perch (Perca fluviatilis; $>20 \mathrm{~cm} L_{\mathrm{T}}$ ), and pikeperch (Sander lucioperca) in Lake Großer Vätersee in the pikeperch-free (19971998) and pikeperch (2001-2002) periods, estimated by multiple mark-recapture census.

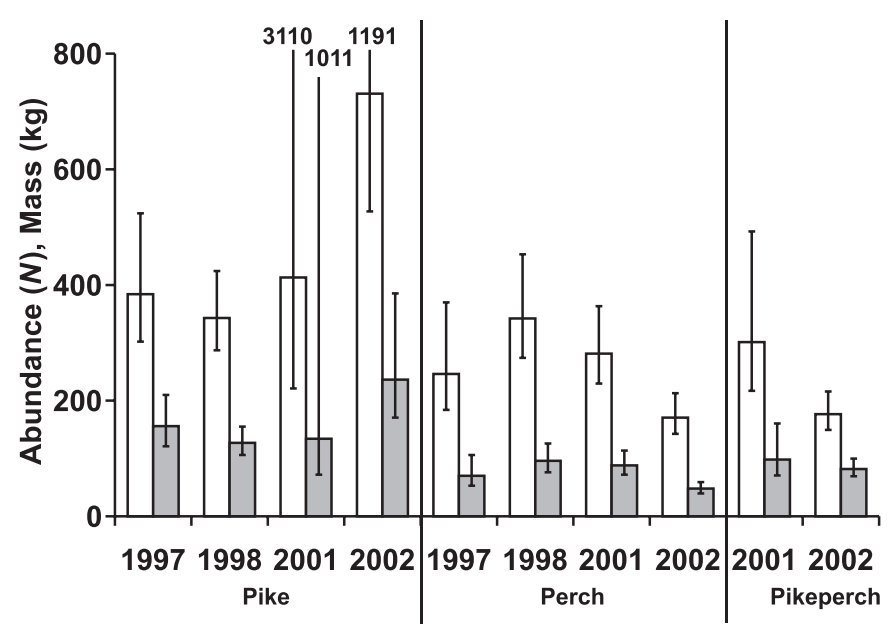

1200) and immediately after nightfall. The fish length was measured and CPUE was calculated per $100 \mathrm{~m}^{2}$ net panel and $2 \mathrm{~h}$ exposure time. CPUE was calculated only for those sampling intervals with $\geq 2$ perch or roach simultaneously caught with littoral and pelagic nets.

\section{Growth and consumption estimates}

For calculating daily rations of northern pike, perch, and pikeperch, a computerized bioenergetics model was used (Fish Bioenergetics, Hanson et al. 1997). Species-specific parameters for perch were taken from Kitchell et al. (1977), for northern pike from Bevelhimer et al. (1985), and for pikeperch from Wysujack and Mehner (2002). Percent composition by mass on a monthly basis was used as diet input. In the pikeperch-free period, water temperature was recorded at a water depth of $1 \mathrm{~m}$ at 1-h intervals throughout the sampling season (ONSET; Optic StowAway ${ }^{\circledR}$ temperature logger). For each day of the simulation period, the mean water temperature was calculated. In the pikeperch period, temperature was interpolated from biweekly measurements using a mean temperature at depths of $0-5 \mathrm{~m}(0.5 \mathrm{~m}$ intervals). Yearly mass increment of fish was modeled between 1 April and 5 November (218 days), because fish diet could not be sampled during winter months. Water temperature was, however, below $8{ }^{\circ} \mathrm{C}$ during the winter, and therefore growth should have been negligible. Mean yearly mass increment per age or length class was used as somatic growth model input, based on age-length keys from scales (northern pike) and opercula (perch; caught in November 2002) or directly determined from individual growth rates of tagged fish (northern pike and pikeperch in 2001-2002, minimum distance between captures $>30$ days). Individual consumption estimates were expanded to population estimates by taking into account the relative abundances of the several age groups or length classes per species of piscivorous fish. For growth comparisons of perch
Table 1. Differences in the abundance of northern pike, perch $\left(>20 \mathrm{~cm} L_{T}\right.$ ), and pikeperch between the years 1997, 1998, 2001, and 2002, based on Student's $t$ test and Bonferroni correction.

\begin{tabular}{llll}
\hline Year & Northern pike & Perch & Pikeperch \\
\hline 2002 vs. 2001 & 0 & - & - \\
2002 vs. 1998 & + & - & nd \\
2002 vs. 1997 & + & - & nd \\
2001 vs. 1998 & 0 & 0 & nd \\
2001 vs. 1997 & 0 & 0 & nd \\
1998 vs. 1997 & 0 & 0 & nd
\end{tabular}

Note: + , increase; - , decrease; 0 , no significant difference; nd, no data.

and northern pike between both periods, the individual growth data were used.

\section{Statistical methods}

Data were checked for normality. The level of significance was $p<0.05$. Predator abundances were tested for differences among years using Student's $t$ test on the reciprocal abundances calculated by the Schumacher and Eschmeyer model (in Ricker 1975) and a Bonferroni correction according to Holm (in Rice 1989). All other tests were calculated using SPSS 9.0 (SPSS Inc. 1999).

\section{Results}

\section{Abundance, biomass, and growth of predatory fish}

During the first month after stocking, 25 pikeperch were found dead in 2001 and 60 in 2002. In both the pikeperchfree (1997 and 1998) and the pikeperch (2001 and 2002) periods, a total of 892 northern pike, 951 perch $(>20 \mathrm{~cm})$, and 245 pikeperch were caught (including recaptures). The number of sampling occasions varied between species and ranged from 10 to 17 each year. Total biomasses of piscivorous fish before pikeperch stocking were $226 \mathrm{~kg}$ and $223 \mathrm{~kg}$ in 1997 and 1998, respectively (Fig. 1). After pikeperch stocking, piscivorous fish biomass rose to $320 \mathrm{~kg}$ and $366 \mathrm{~kg}$ in 2001 and 2002, respectively. Pikeperch contributed $31 \%$ in 2001 and $22 \%$ in 2002 to the total biomass of piscivorous fish. Northern pike biomass was relatively constant between 1997 and 2001 (134-156 kg) but significantly increased in 2002 (236 kg). Partially because of low and heterogeneous recapture rates, the confidence limits of the abundance estimates in northern pike were high in 2001 and 2002 (Fig. 1). Perch biomass never exceeded $96 \mathrm{~kg}$ and dropped below $50 \mathrm{~kg}$ in 2002. After the first stocking in 2001, pikeperch biomass was estimated at $98 \mathrm{~kg}$, whereas $82 \mathrm{~kg}$ were estimated in the second year of stocking. Abundances were significantly higher for northern pike and lower for perch and pikeperch in 2002 than in the previous years (Student's $t$ test, Bonferroni correction, $p<0.05$; Table 1).

Median lengths (minimum-maximum) of northern pike were $36.0(5.0-101.0) \mathrm{cm}$ in 1997-1998 and 32.0 (12.592.0) $\mathrm{cm} L_{T}$ in 2001-2002, whereas median lengths of piscivorous perch were $27.5(20.5-39.5) \mathrm{cm}$ and 28.0 (20.57.0) $\mathrm{cm} L_{T}$ in 1997-1998 and 2001-2002, respectively. Median lengths of pikeperch were $34.0(28.0-49.0) \mathrm{cm}$ and 38.5 (29.5-55.0) $\mathrm{cm} L_{T}$ in 2001 and 2002, respectively. 
Fig. 2. Yearly consumption in terms of biomass of different prey types by populations of northern pike (Esox lucius), perch (Perca fluviatilis; $>20 \mathrm{~cm} L_{\mathrm{T}}$ ), and pikeperch (Sander lucioperca) in the pikeperch-free (1997-1998) and pikeperch (2001-2002) periods in Lake Großer Vätersee, estimated by bioenergetics modeling. Prey are perch (hatched bars), roach (solid bars), other and unidentified fish (stippled bars), Orconectes limosus (open bars), and other invertebrates (shaded bars).

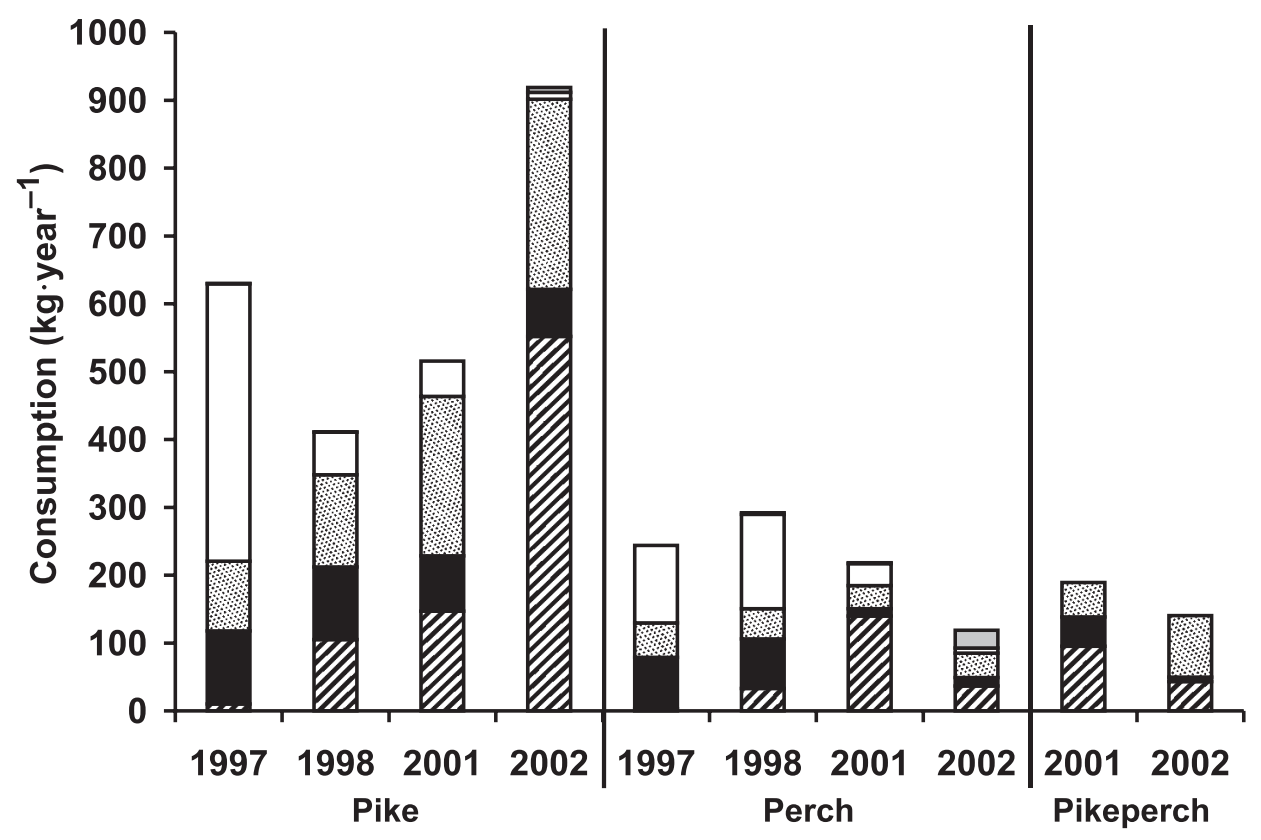

Length-specific growth rates of different size classes of northern pike and perch determined from individual tagging did not differ between the pikeperch and the pikeperch-free period (Mann-Whitney $U$, length class, $p, n$ (pikeperchfree/pikeperch): northern pike: $L_{T}<30 \mathrm{~cm}, p=0.869, n=$ 23/4; $L_{T}=30-45 \mathrm{~cm}, p=0.806, n=48 / 3 ; L_{T}=35-40 \mathrm{~cm}$, $p=0.214, n=59 / 6 ; L_{T}>40 \mathrm{~cm}, p=0.870, n=45 / 9$; perch: $L_{T}=20-25 \mathrm{~cm}, p=0.883, n=26 / 21 ; L_{T}=25-30 \mathrm{~cm}, p=$ $\left.0.795, n=56 / 60 ; L_{T}>30 \mathrm{~cm}, p=0.802, n=42 / 55\right)$.

\section{Diet and consumption}

Spiny-cheek crayfish (Orconectes limosus) and small roach dominated the diet of northern pike and large perch before pikeperch stocking, whereas small perch was the main food item of all three piscivorous species after stocking with pikeperch (Fig. 2). Although consumption of small perch as prey rose from $20 \%$ of total consumption in the pikeperchfree period to $54 \%$ in 2002 , the proportion of small roach declined from more than $20 \%$ in the pikeperch-free period to $15 \%$ and $7 \%$ in the years 2001 and 2002, respectively. Consumption of $O$. limosus declined from $60 \%$ in $1997(523 \mathrm{~kg})$ to only $1 \%(18 \mathrm{~kg}$ ) in 2002 . Other fish consumed were cyprinids other than small roach, juvenile northern pike, ruffe (Gymnocephalus cernuus), pikeperch, and unidentified fish. Other invertebrates consumed were mainly Chaoborus sp. in perch and Asellus sp. in northern pike.

Annual consumption of all piscivorous fishes was in the same range in the years 1997, 1998, and 2001 (874, 703, and $923 \mathrm{~kg}$, respectively) and rose to $1178 \mathrm{~kg}$ in 2002 (Fig. 2). The relative annual consumption rates of the three species largely reflected their contribution to the biomass of the piscivorous guild. Consumption rates were always highest for northern pike $(56 \%-72 \%$ of total consumption in the years 1997, 1998, and 2001, and even 78\% in 2002; Fig. 2).
In contrast, large perch consumed between $24 \%$ and $42 \%$ of the piscivorous guild in the years 1997, 1998, and 2001, but contributed only $10 \%$ to total consumption in 2002. Pikeperch contributed $21 \%$ and $12 \%$ to total consumption in the years 2001 and 2002, respectively. Annual mass-specific individual energy consumption increased in northern pike from about 14300 to $17000 \mathrm{~kJ} \cdot \mathrm{kg}^{-1} \cdot \mathrm{year}^{-1}$, but declined in perch from 13700 to $10700 \mathrm{~kJ} \cdot \mathrm{kg}^{-1} \cdot \mathrm{year}^{-1}$ over the period from 1997 to 2002 (Table 2). In pikeperch, the lowest relative energy consumption rates were estimated.

According to selectivity indices for prey fish, small perch was continuously preferred over small roach by all piscivorous species, and the discrepancy in preference between both species was even enhanced after the stocking with pikeperch (Fig. 3). The differences between the pikeperch-free and the pikeperch periods were significant for both northern pike and large perch as predators (Student's $t$ test, $p<0.05$, northern pike feeding on small perch, $\mathrm{df}=100$; northern pike on small roach, $\mathrm{df}=128$; large perch on small perch, $\mathrm{df}=168$; large perch on small roach, $\mathrm{df}=116$ ).

\section{Diel patterns in habitat use}

Before pikeperch stocking, in an unrepeated sampling operation in June $1997,89 \%$ of large perch $(n=45)$ was caught by gill nets in the pelagic zone during the day, and no large perch have been caught by any passive fishing gear during the night (Haertel et al. 2002). After pikeperch stocking, more large perch were caught in the littoral zone, and the use of littoral habitats even increased from 2001 to 2002 such that almost $69 \%$ of perch were caught in littoral areas during the day in 2002 (Fig. 4). In contrast, pikeperch was caught predominantly in the pelagic zone, although a similarly enhanced use of the littoral zone as in perch was found 
Table 2. Energy consumption per biomass estimated by bioenergetics modeling of northern pike (Esox lucius), perch (Perca fluviatilis; $>20 \mathrm{~cm} L_{T}$ ), and pikeperch (Sander lucioperca) in Lake Großer Vätersee before (1997-1998) and after (20012002) stocking with pikeperch.

\begin{tabular}{llll}
\hline & \multicolumn{3}{l}{ Specific consumption $\left(\mathrm{kJ} \cdot \mathrm{kg}^{-1} \mathrm{year}^{-1}\right)$} \\
\cline { 2 - 4 } & Northern pike & Perch & Pikeperch \\
\hline 1997 & 14284 & 13668 & \\
1998 & 14211 & 11637 & \\
2001 & 15923 & 10122 & 8682 \\
2002 & 17020 & 10668 & 7620 \\
\hline
\end{tabular}

Fig. 3. Index of selectivity \pm standard deviation (Strauss 1979) for small perch (Perca fluviatilis) and small roach (Rutilus rutilus) in the diet of northern pike (Esox lucius), large perch (>20 $\mathrm{cm} L_{\mathrm{T}}$ ), and pikeperch (Sander lucioperca) in Lake Großer Vätersee in the years 1998 (open bars) and 2002 (shaded bars). Asterisks (*) indicate that selectivities were significantly different between the two years ( $t$ test, $p<0.05$ ).

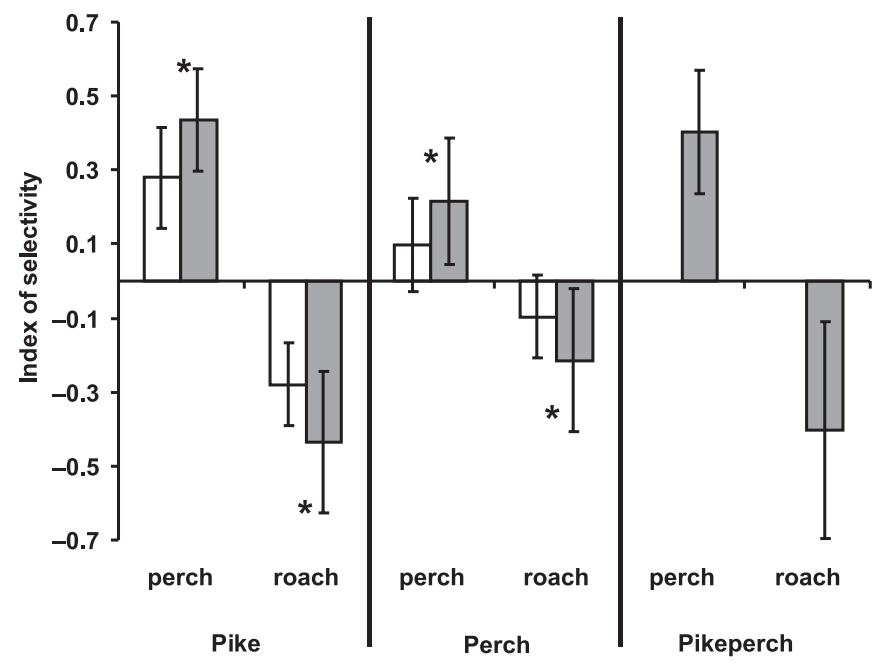

in 2002 (Fig. 4). Further, although perch was caught by gill nets only during day and twilight, pikeperch was also caught during night. Northern pike was only occasionally $(n=11)$ caught by gill nets (never during night). During both the pikeperch-free (Haertel et al. 2002) and pikeperch periods, northern pike were predominantly caught in Chara sp. beds («3 $\mathrm{m}$ depth) or in reed stands in the littoral zone.

\section{Abundance and distribution of prey}

Biomasses of prey populations (mean \pm SD) were 25.8 $( \pm 1.2) \mathrm{kg} \cdot \mathrm{ha}^{-1}$ for small roach and $7.2( \pm 1.6) \mathrm{kg} \cdot \mathrm{ha}^{-1}$ for small perch in 1998 (Haertel et al. 2002) and 14.7 $( \pm 4.1) \mathrm{kg} \cdot \mathrm{ha}^{-1}$ for small roach and $10.4( \pm 1.7) \mathrm{kg} \cdot \mathrm{ha}^{-1}$ for small perch in 2002 (Fig. 5). The number of sampling occasions were 19 and 17 in 1998 and 13 and 16 in 2002 for small roach and small perch, respectively. In the pikeperchfree period, small roach exclusively used the littoral zone during daytime, whereas almost all small roach were caught in the pelagic zone during night (Fig. 6). This was different in the pikeperch period when small roach reduced its diel horizontal migration and used the pelagic zone less rigor-
Fig. 4. Percent of gill net catch (catch per unit effort, CPUE; columns: median of all catches with $\geq 2$ individuals) of perch (Perca fluviatilis; $>20 \mathrm{~cm} L_{\mathrm{T}}$ ) and pikeperch (Sander lucioperca) in the pikeperch period obtained from littoral (open bars) or pelagic (shaded bars) habitats in Lake Großer Vätersee during day, twilight (twil.), and night. Numbers above columns indicate the number of sampling occasions, numbers in parentheses indicate the number of fishes caught for distribution estimates. Please note that no large perch were caught at all during two nightly sampling occasions in 2002.

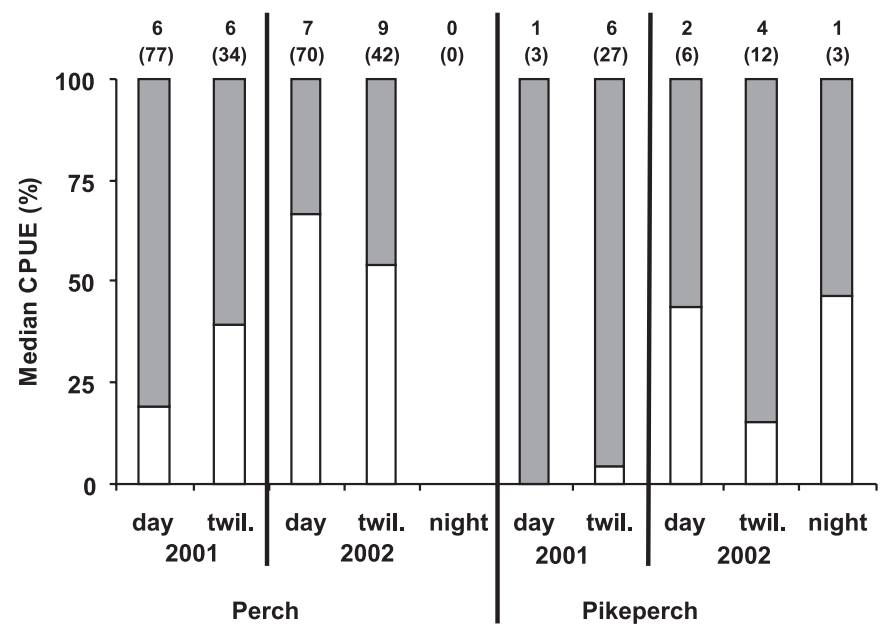

ously during night. No difference in diel habitat use was observed for small perch, which were caught mostly in the littoral zone during day. No conclusion can be drawn from the gill net catches about the habitat use of small perch during night after the pikeperch stocking because only two individuals were caught during two sampling occasions. In contrast, perch of all size classes were observed resting in high numbers in shallow littoral areas before and after the pikeperch stocking during night (Haertel et al. 2002; T. Schulze, personal observations) and were not even caught with active fishing methods in the pelagic zone (purse seine) during night in the pikeperch period (H. Dörner, unpublished data; see Mehner et al. (2005b) for details on fishing methods). This indicates a nearly exclusive inactive use of littoral habitats by small perch during night in the pikeperch period, whereas active perch were caught in both habitats during night in the pikeperch-free period.

\section{Discussion}

Our study demonstrates that the introduction of a new predator type had strong impacts on the residential fish community in Lake Großer Vätersee on both the prey and predator levels. The lake-wide piscivore biomass increased 1.42-1.64 times as a result of pikeperch stocking and the accompanying increase in northern pike abundance. The biomass of piscivorous fish in the pelagic area almost doubled as a result of pikeperch stocking in comparison with the period before stocking when large perch was the sole pelagic predator. Therefore, a severe density-mediated perturbation could be expected. Beyond the density-mediated effects on the prey fish population (consumption rates of predators), changes in a behavioral trait (reduced diel horizontal migration 
Fig. 5. Abundance (open bars) and biomass (shaded bars) \pm standard deviation of small roach (Rutilus rutilus; 6-16 $\mathrm{cm} L_{\mathrm{T}}$ ) and small perch (Perca fluviatilis; 6-15 $\mathrm{cm} L_{\mathrm{T}}$ ) in Lake Großer Vätersee in the periods before (1988) and after (2002) pikeperch (Sander lucioperca) stocking, as estimated by multiple markrecapture census.

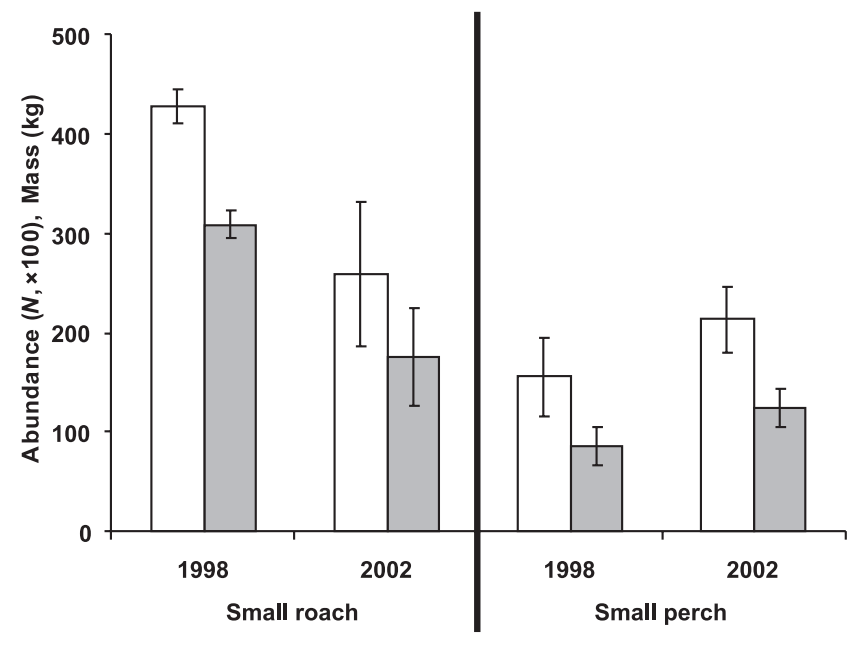

of small roach) were also observed. Furthermore, among the residential predators, the introduced pikeperch induced both density-mediated effects (cannibalism and intraguild predation) and changes in habitat use and prey selectivity. The latter may be a trait-mediated indirect effect of the behavioral changes of the prey species (reduced diel horizontal migration). These complex interactions have, to the best of our knowledge, never been reported in empirical studies to date and underline that the immediate expectation, i.e., introduced predators suppressing unwanted prey fish and improving fisheries yield, will not necessarily be fulfilled because of compensatory mechanisms affecting the piscivorous guild.

Pikeperch stocking affected habitat use and diet composition of piscivorous perch. Because both species are predominantly pelagic hunters, strong interspecific competition for pelagic-living prey fish could be expected (Craig 1987). However, according to literature, the main diel activity phases differ between perch and pikeperch with pikeperch being more active during the twilight and night phases and perch being a day-active species (Craig 1987). In contrast, in Lake Großer Vätersee diel gill net catches of large perch and pikeperch indicated a stronger temporal overlap. Although perch were almost exclusively caught during day and twilight, pikeperch were caught over the full diel cycle, reflecting a simultaneous hunting activity of both species at least during daytime and twilight. Also, the spatial segregation between large perch and pikeperch remained weak, with both species being caught in the littoral and pelagic zones. Accordingly, there was only low niche segregation between perch and pikeperch, and competition was probably strong. However, there was a strong tendency for perch to increasingly respond to the pelagic presence of pikeperch by shifting their daytime habitat towards a stronger use of the littoral area as a higher proportion of perch was caught in nearshore areas in 2002 as compared with 2001, and the differences were even more pronounced in comparison with the
Fig. 6. Percent of gill net catch (catch per unit effort, CPUE; columns: median of all catches with $\geq 2$ individuals) of small roach (Rutilus rutilus) and small perch (Perca fluviatilis) in the periods before (PP free; 1997-1998) and after (PP; 2001-2002) pikeperch (Sander lucioperca) stocking, obtained from littoral (open bars) or pelagic (shaded bars) habitats in Lake Großer Vätersee during day and night. Numbers above columns indicate the numbers of sampling occasions, numbers in parentheses indicate the number of fishes caught for distribution estimates.

Please note that only two small perch were caught during two nightly sampling occasions in 2002, which were not considered to be representative of habitat use.

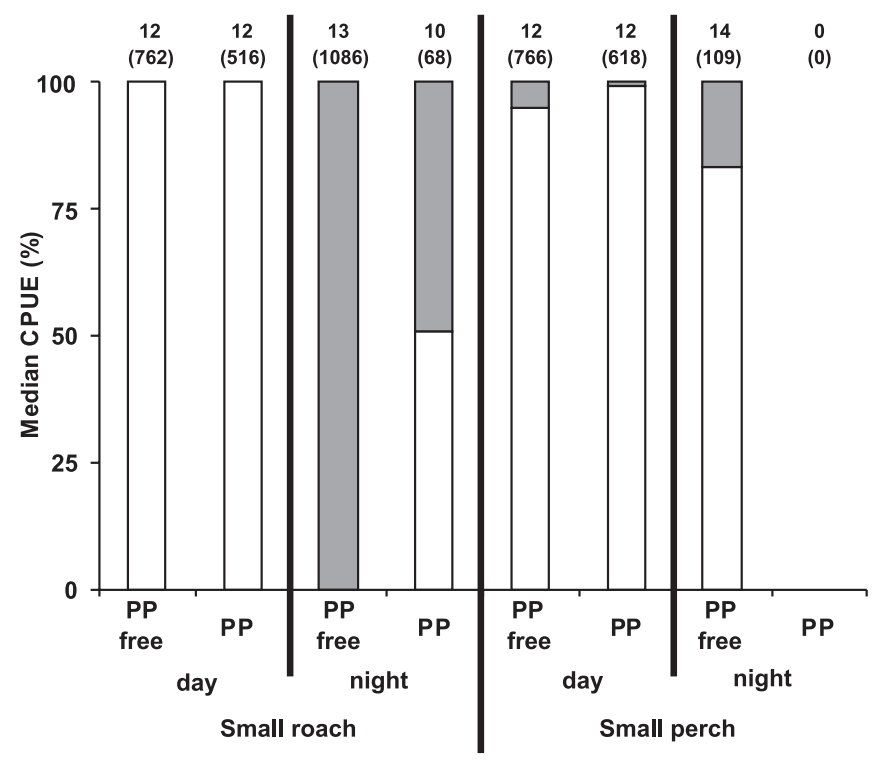

situation before pikeperch stocking (Haertel et al. 2002). This may indicate strong interference competition for the pelagic zone, with the larger pikeperch being the stronger competitor. Aggressive pelagic interference was also found to be responsible for reduced vertical space use by Dolly Varden (Salvelinus malma) living in sympatry with cutthroat trout (Oncorhynchus clarkii) (Hindar et al. 1988). Furthermore, size is an important factor determining competitive displacements in predator communities in which intraguild predation occurs (Fedriani et al. 2000; Suutari et al. 2004), thus underlining the possibility of asymmetric interference competition between the larger pikeperch $\left(55 \mathrm{~cm}\right.$ maximum $\left.L_{T}\right)$ and the smaller perch $\left(39.5 \mathrm{~cm}\right.$ maximum $\left.L_{T}\right)$.

A different impact of pikeperch stocking was found on northern pike. Because the feeding habitats differ between northern pike and pikeperch, a strong spatial segregation could be expected. Indeed, in Lake Großer Vätersee, only a few northern pike (five in each year in 2001 and 2002; Schulze 2005) were caught by the pelagic or deep littoral gill nets, indicating a close association of northern pike with reed stands and Chara sp. beds. In contrast, no pikeperch were caught in the littoral reed stands where northern pike occurred during the day and night. Because there was no response in habitat preferences or activity patterns of northern pike in response to pikeperch stocking, competition for feeding habitat between both predators was assumed to be very low in Lake Großer Vätersee as a consequence of the stable 
spatial segregation between northern pike and pikeperch. Comparably, habitat use and hence diet compositions of northern pike and pikeperch differed in an empirical study in Lake Peipsi (Kangur and Kangur 1998) such that the authors concluded that interspecific competition between these predators was probably not strong. However, northern pike and pikeperch may still compete for the same food resources in Lake Großer Vätersee because of the diel and seasonal migrations of small fish between littoral and pelagic sites (this study; see also Jacobsen and Berg 1998; Okun and Mehner 2005).

Northern pike may have even benefited from stocking with pikeperch. In direct comparison between the pikeperch-free and the pikeperch periods, northern pike abundance was significantly higher in 2002 than the years before pikeperch stocking, and biomass almost doubled after the pikeperch introduction. An explanation may be a higher recruitment from larvae into the juvenile size classes, indicated by the declining median length of northern pike in the pikeperch period. Recruitment is correlated with the availability of food and vegetative shelter for the juveniles against cannibalism (Craig 1996; Skov and Koed 2004). Because of altered habitat use and abundances of prey fish, the prey availability in the littoral zone increased after the introduction of pikeperch (please see below for further discussion). Specific consumption rates of northern pike were indeed higher in the pikeperch period, and cannibalism in northern pike was found only in very few cases in Lake Großer Vätersee (Schulze 2005).

According to the improved performance of northern pike after pikeperch stocking, perch was also the inferior competitor to northern pike in the littoral zone. This may be indicated by the decreased specific consumption rates in perch after the pikeperch stocking and is in accordance with other studies in which juvenile northern pike was found to be the more effective forager compared with perch in complex littoral structures (Jacobsen and Perrow 1998). Furthermore, only the northern pike growth rates increased in experiments when northern pike only treatments were contrasted with treatments in which perch and northern pike co-occurred. In contrast, perch could not benefit from competitive release because their growth rates were similar in both treatments (Eklöv and VanKooten 2001). However, the specific growth rates (one of the input parameters of the bioenergetics models) of northern pike and perch were not different between the two periods in the present study. Consequently, in Lake Großer Vätersee, piscivorous perch responded to competition with pikeperch in the pelagic zone by a partial habitat shift and increased cannibalism, but was faced with similarly strong competition and a higher predation rate on perch juveniles by northern pike in the littoral areas. Therefore, both pikeperch and northern pike are supposed to be the specialists for piscivorous feeding in their favored habitats, leading to the more generalist perch being sandwiched between northern pike (littoral zone) and pikeperch (pelagic zone) and becoming the weaker competitor for fish. A similar sandwiching was described for juvenile perch switching between planktivory and benthivory in competition with the benthivorous specialist ruffe and the planktivorous specialist roach such that perch growth rates were always lower than those of the competing species (Bergman and Greenberg 1994). It can be assumed, therefore, that specialists with a highly efficient feeding strategy in one habitat may outcompete a generalist (perch) in relatively stable environments like Lake Großer Vätersee. The generalist is then forced to respond with diet and (or) habitat shifts to avoid severe competition (Larkin 1956).

The interactions between the predators were furthermore directly influenced by changes in prey fish abundance and behavior. Small roach, the dominant prey species in the pikeperch-free period, responded to pikeperch stocking with reduced diel horizontal migrations. In the pikeperch-free period, small roach inhabited the littoral zone during the day, being protected against predation by large perch in the pelagic zone, but moved into the zooplankton-richer pelagic area during the night (Haertel et al. 2002). After pikeperch introduction, however, the occurrence of small roach in littoral habitats also remained high during the night. Such a shift in a behavioral trait was also observed in other lakes in response to pikeperch stocking (Brabrand and Faafeng 1993). Accordingly, the availability of small roach in the pelagic areas declined for both pikeperch and perch, but increased for northern pike in the littoral zone, which may have contributed to the higher recruitment of northern pike. Brabrand and Faafeng (1993) similarly argued that the modification of roach behavior by pikeperch stocking in Lake Gjersjoen (Norway) may have increased the prey availability for littoral predators.

The abundance of the alternative prey species, small perch, slightly increased in the years after pikeperch stocking. Further, small perch inhabited mostly the littoral areas during the day and were exclusively found in littoral habitats during the night in the pikeperch period. This predominant littoral occurrence may have contributed to the habitat shifts of the piscivorous perch and the partial littoral habitat use of pikeperch and has furthermore increased the availability of perch as prey for northern pike. As a consequence, cannibalism and intraguild predation on small perch substantially increased in 2001, which may have led to a reduced recruitment from small to large perch and eventually to a reduced density of large perch in 2002. Further, the predation impact relative to the standing stock of small perch became very high in 2002. Nevertheless, year-class strength of small perch in 2002 was high, indicated by slightly higher abundances of small perch in spite of the high predation pressure. Introduction of pikeperch into Scandinavian waters inhabited by perch resulted in comparable interactions where predation on juvenile perch by pikeperch explained the strong decrease in commercial catches of perch, and also, in naturally sympatric populations, perch catches were inversely correlated with those of pikeperch (Svärdson and Molin 1973).

Overall, feeding of all piscivores on the prey populations was asymmetrical, although both small perch and small roach concentrated in the littoral zone. Consumption on perch increased, whereas that on small roach decreased. Firstly, this simply reflects the differing population developments of small perch and small roach, with perch densities increasing and roach densities declining after pikeperch stocking. Also, in other lakes, diet composition of piscivorous perch, northern pike, and pikeperch were mainly influenced 
by relative availabilities of prey species (Popova and Sytina 1977; Fedorova and Drozzhina 1982; Dörner et al. 2003). Secondly, selectivity indices for roach feeding did decline and that for perch increased. Small perch are very vulnerable to predators as they have to move continuously while feeding on benthic organisms and therefore face a high risk of encountering predators. In contrast, roach show effective behavioral antipredator traits, such as shoaling and jumping out of the water, that have been found to reduce the number of roach eaten by littoral predators (Christensen and Persson 1993; Eklöv and Persson 1995; Persson and Eklöv 1995). Further, in a habitat structured by artificial vegetation (Christensen and Persson 1993) similar to the reed stands in the littoral zone of Lake Großer Vätersee, small perch was found to be preferred over small roach by predators because of different antipredator traits. Therefore, small roach were probably less vulnerable than small perch to all piscivorous predators in Lake Großer Vätersee after pikeperch had been introduced, and thus passive selectivity (sensu Turesson et al. 2002) for roach feeding declined and that for perch increased under strong predation pressure leading to strong intraguild predation on small perch. Similar findings were made at high piscivorous fish biomass in Bautzen Reservoir, where small benthivorous perch were the preferred prey of piscivorous perch, pikeperch, and eel (Dörner et al. 1999, 2003; Dörner and Benndorf 2003).

The preferential consumption of small perch indicated that besides competitive interactions, predator-prey relationships between the predators also became increasingly important and contributed decisively to the density-mediated effects of the pikeperch introduction. The mutual predation on potential competitors, both within and across the species borders, is widespread in many aquatic and terrestrial species (Arim and Marquet 2004) and has fundamental impacts on food web dynamics and ecosystem stability (Claessen et al. 2004). In pikeperch, strong inter- and intra-cohort cannibalism was found to stabilize year-class strengths and was seen as population density self-regulation (Frankiewicz et al. 1999). Furthermore, adaptive feeding of predators stabilizes food webs (Murdoch 1969) and promotes species coexistence in modeled systems because adaptive foraging changes interaction strength in food webs, which relaxes competition between species (Krivan 2003).

The results presented here give empirical support for the compensatory effects of adaptive feeding strategies in predators, which include cannibalism and intraguild predation. As a consequence, for Lake Großer Vätersee, we expect that the total biomass of piscivorous fish will fall back to that biomass that was estimated before stocking because the piscivorous trophic level in four-level mesotrophic lakes is strongly dependent on the productivity of the system (Persson et al. 1992). Indeed, predation pressure of piscivorous fish on their prey populations was already high before the stocking (Haertel et al. 2002) and the trophic state of the lake has not changed during the experiment. Thus, although predator biomass was substantially enhanced, we suggest that several selfregulating mechanisms will, in the long term, prevent a higher energy transfer to the piscivores in comparison with the situation before stocking.

Nevertheless, populations of the residential predator species responded very differently to stocking with a new predator type in mesotrophic lakes. Our results suggest that introductions and stocking programs with pikeperch or other piscivorous fish species are likely to result in a decrease of guild member abundances because of increased competition and trait-mediated interactions (i.e., changes in behavioral traits leading to alterations in prey selectivity as in the present study). Accordingly, each introduction of a new piscivorous fish species might be a trade-off (in the long term) between gaining a new species for commercial or game fisheries and altering or even decreasing the abundances of the residential piscivorous species, especially when prey resources are already limited.

\section{Acknowledgements}

We thank Christian Helms and Alexander Türck for supporting all kinds of labor-intensive fieldwork. We thank all members of the Department of Biology and Ecology of Fishes and the Lake Vätersee working group for their support during the stocking and fishing programs and for valuable discussions. The study was financed by the German Research Foundation (DFG, EC 146/2-1+2, and ME 1686/4-1+2).

\section{References}

Arim, M., and Marquet, P.A. 2004. Intraguild predation: a widespread interaction related to species biology. Ecol. Lett. 7: 557-564.

Bergman, E., and Greenberg, L.A. 1994. Competition between a planktivore, a benthivore, and a species with ontogenic diet shifts. Ecology, 75: 1233-1245.

Bevelhimer, M.S., Stein, R.A., and Carline, R.F. 1985. Assessing significance of physiological differences among three esocids with a bioenergetics model. Can. J. Fish. Aquat. Sci. 42: 57-69.

Brabrand, A., and Faafeng, B. 1993. Habitat shift in roach (Rutilus rutilus) induced by pikeperch (Stizostedion lucioperca) introduction: predation risk versus pelagic behaviour. Oecologia, 95: 38-46.

Carpenter, S.R., and Kitchell, J.F. 1993. The trophic cascade in lakes. Cambridge University Press, Cambridge, UK.

Christensen, B., and Persson, L. 1993. Species-specific antipredatory behaviors - effects on prey choice in different habitats. Behav. Ecol. Sociobiol. 32: 1-9.

Claessen, D., De Roos, A.M., and Persson, L. 2004. Population dynamic theory of size-dependent cannibalism. Proc. R. Soc. Lond. Ser. B Biol. Sci. 271: 333-340.

Coblentz, B.E. 1990. Exotic organisms: a dilemma for conservation biology. Conserv. Biol. 4: 261-265.

Craig, J.F. 1987. The biology of perch and related fish. Croom Helm Ltd., Kent, UK.

Craig, J.F. 1992. Human-induced changes in the composition of fish communities in African Great Lakes. Rev. Fish Biol. Fish. 2: 93-124.

Craig, J.F. 1996. Pike: biology and exploitation. Chapman \& Hall, London, UK.

Dörner, H., and Benndorf, J. 2003. Piscivory by large eels on young-of-the-year fishes: its potential as a biomanipulation tool. J. Fish Biol. 62: 491-494. doi:10.1046/j.0022-1112.2003.00035.x.

Dörner, H., Wagner, A., and Benndorf, J. 1999. Predation by piscivorous fish on age- 0 fish: spatial and temporal variability in a biomanipulated lake (Bautzen reservoir, Germany). Hydrobiologia, 408-409: 36-46.

Dörner, H., Berg, S., Jacobsen, L., Hülsmann, S., Brojerg, M., and Wagner, A. 2003. The feeding behaviour of large perch (Perca 
fluviatilis (L.)) in relation to food availability: a comparative study. Hydrobiologia, 506-509: 427-434.

Eklöv, P. 1992. Group foraging versus solitary foraging efficiency in piscivorous predators - the perch, Perca fluviatilis, and pike, Esox lucius, patterns. Anim. Behav. 44: 313-326.

Eklöv, P., and Persson, L. 1995. Species-specific antipredator capacities and prey refuges - interactions between piscivorous perch (Perca fluviatilis) and juvenile perch and roach (Rutilus rutilus). Behav. Ecol. Sociobiol. 37: 169-178.

Eklöv, P., and VanKooten, T. 2001. Facilitation among piscivorous predators: effects of prey habitat use. Ecology, 82: 2486-2494.

Fedorova, G.V., and Drozzhina, K.S. 1982. Daily feeding rhythm of pikeperch, Stizostedion lucioperca, and perch, Perca fluviatilis, from Lake Ladoga. J. Ichthyol. 22: 52-60.

Fedriani, J.M., Fuller, T.K., Sauvajot, R.M., and York, E.C. 2000. Competition and intraguild predation among three sympatric carnivores. Oecologia, 125: 258-270.

Frankiewicz, P., Dabrowski, K., Martyniak, A., and Zalewski, M. 1999. Cannibalism as a regulatory force of pikeperch, Stizostedion lucioperca (L.), population dynamics in the lowland Sulejow reservoir (Central Poland). Hydrobiologia, 408-409: 47-55.

Haertel, S.S., Baade, U., and Eckmann, R. 2002. No general percid dominance at mesotrophic lake conditions: insights from the quantification of predator-prey interactions. Limnologica, 32: 1-13.

Hanson, J.M., and Leggett, W.C. 1986. Effect of competition between two freshwater fishes on prey consumption and abundance. Can. J. Fish. Aquat. Sci. 43: 1363-1372.

Hanson, P.C., Johnson, T.B., Schindler, D.E., and Kitchell, J.F. 1997. Fish bioenergetics. Version 3.0 for Windows. University of Wisconsin-Madison, Centre for Limnology and University of Wisconsin Sea Grant Institute, Madison, Wisconsin.

Hansson, L.A., Annadotter, H., Bergman, E., Hamrin, S.F., Jeppesen, E., Kairesalo, T., Luokkanen, E., Nilsson, P.A., Søndergaard, M., and Strand, J. 1998. Biomanipulation as an application of foodchain theory: constraints, synthesis, and recommendations for temperate lakes. Ecosystems, 1: 558-574.

Hindar, K., Jonsson, B., Andrew, J.H., and Northcote, T.G. 1988. Resource utilization of sympatric and experimentally allopatric cutthroat trout and Dolly Varden charr. Oecologia, 74: 481-491.

Hölker, F., and Mehner, T. 2005. Simulation of trait- and densitymediated indirect effects induced by piscivorous predators. Basic Appl. Ecol. 6: 289-300.

Jacobsen, L., and Berg, S. 1998. Diel variation in habitat use by planktivores in field enclosure experiments: the effect of submerged macrophytes and predation. J. Fish Biol. 53: 1207-1219.

Jacobsen, L., and Perrow, M.R. 1998. Predation risk from piscivorous fish influencing the diel use of macrophytes by planktivorous fish in experimental ponds. Ecol. Freshw. Fish, 7: 78-86.

Kangur, A., and Kangur, P. 1998. Diet composition and size-related changes in the feeding of pikeperch, Stizostedion lucioperca (Percidae), and pike, Esox lucius (Esocidae), in the Lake Peipsi (Estonia). Ital. J. Zool. 65: 255-259.

Kasprzak, P., Gervais, F., Adrian, R., Weiler, W., Radke, R.J., Jäger, I., Riest, S., Siedel, U., Schneider, B., Böhme, M., Eckmann, R., and Walz, N. 2000. Trophic characterization, pelagic food web structure and comparison of two mesotrophic lakes in Brandenburg (Germany). Int. Rev. Hydrobiol. 85: 167-189.

Kitchell, J.F., Stewart, D.J., and Weininger, D. 1977. Applications of a bioenergetics model to perch (Perca flavescens) and walleye (Stizostedion vitreum vitreum). J. Fish. Res. Board Can. 34: 1922-1935.

Krivan, V. 2003. Competitive co-existence caused by adaptive predators. Evol. Ecol. Res. 5: 1163-1182.
Larkin, P.A. 1956. Interspecific competition and population control in freshwater fish. J. Fish. Res. Board Can. 13: 327-342.

Lathrop, R.C., Johnson, B.M., Johnson, T.B., Vogelsang, M.T., Carpenter, S.R., Hrabik, T.R., Kitchell, J.F., Magnuson, J.J., Rudstam, L.G., and Stewart, R.S. 2002. Stocking piscivores to improve fishing and water clarity: a synthesis of the Lake Mendota biomanipulation project. Freshw. Biol. 47: 2410-2424.

Lehtonen, H., Miina, T., and Frisk, T. 1984. Natural occurrence of pike-perch (Stizostedion lucioperca (L.)) and success of introduction in relation to water quality and lake area in Finland. Aqua Fenn. 14: 189-196.

Maitland, P.S., and Campbell, R.N. 1992. Freshwater fishes. Harper Collins Publishers, London, UK.

Mehner, T., Arlinghaus, R., Berg, S., Dörner, H., Jacobsen, L., Kasprzak, P., Koschel, R., Schulze, T., Skov, C., Wolter, C., and Wysujack, K. 2004. How to link biomanipulation and sustainable fisheries management: a step-by-step guideline for lakes of the European temperate zone. Fish. Manag. Ecol. 11: 261-275.

Mehner, T., Diekmann, M., Brämick, U., and Lemcke, R. $2005 a$. Composition of fish communities in German lakes as related to lake morphology, trophic state, shore structure and human-use intensity. Freshw. Biol. 50: 70-85.

Mehner, T., Ihlau, J., Dörner, H., and Hölker, F. 2005b. Can feeding of fish on terrestrial insects subsidize the nutrient pool of lakes? Limnol. Oceanogr. 50: 2022-2031.

Murdoch, W.W. 1969. Switching in general predators: experiments on predator specificity and the stability of prey populations. Ecol. Monogr. 39: 335-354.

Okun, N., and Mehner, T. 2005. Distribution and feeding of juvenile fish on invertebrates in littoral reed (Phragmites) stands. Ecol. Freshw. Fish, 14: 139-149.

Otis, D.L., Burnham, K.P., White, D.C., and Anderson, D.R. 1978. Statistical inference from capture data on closed animal populations. Wildl. Monogr. 62: 1-135.

Persson, L. 1986. Effects of reduced interspecific competition on resource utilization in perch (Perca fluviatilis). Ecology, 67: $355-364$.

Persson, L., Diehl, S., Johansson, L., Andersson, G., and Hamrin, S. 1992. Trophic interactions in temperate lake ecosystems: a test of food chain theory. Am. Nat. 140: 59-84.

Persson, L., and Eklöv, P. 1995. Prey refuges affecting interactions between piscivorous perch and juvenile perch and roach. Ecology, 76: $70-81$.

Polis, G.A., Myers, C.A., and Holt, R.D. 1989. The ecology and evolution of intraguild predation: potential competitors that eat each other. Annu. Rev. Ecol. Syst. 20: 297-330.

Popova, O.A., and Sytina, L.A. 1977. Food and feeding relations of Eurasian perch (Perca fluviatilis) and pikeperch (Stizostedion lucioperca) in various waters of the USSR. J. Fish. Res. Board Can. 34: 1559-1570.

Rice, W.R. 1989. Analyzing tables of statistical tests. Evolution, 43: 223-225.

Ricker, W.E. 1975. Computation and interpretation of biological statistics of fish populations. Bull. Fish. Res. Board Can. 191: 1-382.

Schoener, T.W. 1974. Resource partitioning in ecological communities. Science (Washington, D.C.), 185: 27-39.

Schulze, T. 2005. Changes in structure and function of the fish community in a mesotrophic lake ecosystem after stocking a non-native top predator. PhD. thesis, University of Potsdam, Potsdam, Germany.

Simberloff, D. 1981. Community effects of introduced species. In Biotic crises in ecological and evolutionary time. Edited by M.H. Nitecki. Academic Press, New York. pp. 53-81. 
Skov, C., and Koed, A. 2004. Habitat use of 0+year pike in experimental ponds in relation to cannibalism, zooplankton, water transparency and habitat complexity. J. Fish Biol. 64: 448-459.

SPSS Inc. 1999. SPSS 9.0. SPSS Inc., Chicago, Illinois.

Strauss, R.E. 1979. Reliability estimates for Ivlev's electivity index, the forage ratio, and a proposed linear index of food selection. Trans. Am. Fish. Soc. 108: 344-352.

Suutari, E., Rantala, M.J., Salmela, J., and Suhonen, J. 2004. Intraguild predation and interference competition on the endangered dragonfly Aeshna viridis. Oecologia, 140: 135-139.

Svärdson, G., and Molin, G. 1973. The impact of climate on scandinavian population of the sander, Stizostedion lucioperca (L.). Inst. Freshw. Res. Drottningholm, 53: 112-139.

Turesson, H., Persson, A., and Brönmark, C. 2002. Prey size selection in piscivorous pikeperch (Stizostedion lucioperca) includes active prey choice. Ecol. Freshw. Fish, 11: 223-233.
Welcomme, R.L. 2001. Inland fisheries. Ecology and management. Blackwell Science, Oxford, UK.

Werner, E.E., and Gilliam, J.F. 1984. The ontogenetic niche and species interactions in size-structured populations. Annu. Rev. Ecol. Syst. 15: 393-425.

Werner, E.E., and Hall, D.J. 1977. Habitat partitioning in a freshwater fish community. J. Fish. Res. Board Can. 34: 360-370.

White, G.C., Anderson, D.R., Burnham, K.P., and Otis, D.L. 1982. Capture-recapture and removal methods for sampling closed populations. Los Alamos National Laboratory, Los Alamos, New Mexico.

Wysujack, K., and Mehner, T. 2002. Comparison of losses of planktivorous fish by predation and seine-fishing in a lake undergoing long-term biomanipulation. Freshw. Biol. 47: 2425-2434. 